\title{
Erratum to: Counselors' Clinical Use of Definitive Drug Testing Results in Their Work with Substance-Use Clients: a Qualitative Study
}

\author{
Adam Rzetelny ${ }^{1,3} \cdot$ Barbara Zeller $^{2} \cdot$ Nicholas Miller $^{1,3} \cdot$ \\ Kathy Egan City ${ }^{1,3} \cdot$ Kenneth L. Kirsh ${ }^{1,3}$. \\ Steven D. Passik ${ }^{1,3}$
}

Published online: 4 September 2015

(C) Springer Science+Business Media New York 2015

\section{Erratum to: Int J Ment Health Addiction DOI: 10.1007/s11469-015-9569-7}

Please note that the word "illicit" should be read as "elicit" in the following 3 spots in this article:

Twice on the 5th page of the article, in the first paragraph under the heading "Materials" (on line 3 and line 8); and once on the 6th page of the article, in the first full paragraph on that page (on line 8).

The online version of the original article can be found at/http:dx.doi.org/10.1007/s11469-015-9569-7.

\section{Adam Rzetelny}

adam.rzetelny@millenniumresearchinstitute.org

1 Millennium Health, 16980 Via Tazon, San Diego, CA 92127, USA

2 Housing Enterprise for the Less Privileged/Project Samaritan Inc (HELP/PSI), New York, NY, USA

3 Millennium Research Institute, San Diego, CA, USA 